\title{
ТЕХНИКО-ТЕХНОЛОГИЧЕСКИЕ
} ИННОВАЦИИ

DOI: http://dx.doi.org/10.15688/jvolsu10.2014.5.2

УДК 618.39

ББК 28.072

\section{THE INFLUENCE OF MELAFEN \\ ON STRUCTURAL PROPERTIES \\ OF PHOSPHOLIPID MEMBRANES}

\author{
Alekseeva Olga Mikhaylovna

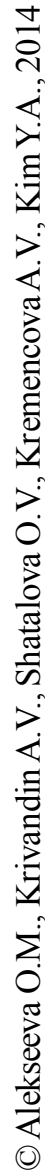 \\ Candidate of Biological Sciences, Senior Researcher, \\ Institute of Biochemical Physics named after N.M. Emanuel of RAS \\ olgavek@yandex.ru \\ Kosygina St., 4, 119334 Moscow, Russian Federation \\ Krivandin Aleksey Vladimirovich \\ Candidate of Physical and Mathematical Sciences, Leading Researcher, \\ Institute of Biochemical Physics named after N.M. Emanuel of RAS \\ olgavek@yandex.ru \\ Kosygina St., 4, 119334 Moscow, Russian Federation

\section{Shatalova Olga Vladimirovna} \\ Researcher, \\ Institute of Biochemical Physics named after N.M. Emanuel of RAS \\ olgavek@yandex.ru \\ Kosygina St., 4, 119334 Moscow, Russian Federation

\section{Krementsova Anna Vladimirovna} \\ Candidate of Physical and Mathematical Sciences, Leading Researcher, \\ Institute of Biochemical Physics named after N.M. Emanuel of RAS \\ olgavek@yandex.ru \\ Kosygina St., 4, 119334 Moscow, Russian Federation
}




\title{
Kim Yuriy Aleksandrovich
}

Doctor of Physical and Mathematical Sciences, Leading Researcher, Institute for Biological Instrumentation of RAS

ibp@ibp-ran.ru

Institutskaya St., 7, 142290 Pushchino, Russian Federation

\begin{abstract}
The paper studies the effect of aqueous solutions of melamine salt of phosphonic acid (Melafen), used in crop production, on structural and thermodynamic properties of phospholipid membranes. The multilamellar liposomes formed from individual synthetic dimyristoylphosphatidylcholine (DMPC), or natural phospholipid mixture (egg lecithin) was studied by differential scanning microcalorimetry (DSC) and small-angle X-ray scattering (SAXS).

The method of DSC was used to appraise the influence of Melafen aqueous solutions $\left(10^{-17} \mathrm{M}\right.$ to $\left.10^{-3} \mathrm{M}\right)$ on thermodynamic parameters of lipid melting (temperature, enthalpy and cooperation of phase transition) in suspension of liposomes formed from DMPC. On the basis of DSC data it was concluded that the microdomain structural organization of DMPC membranes was altered by Melafen aqueous solutions as polymodal type.

We did not reveal by the SAXS method any noticeable integral structural changes in membranes of egg lecithin in multilamellar liposomes as well as in their stacking parameters (period and degree of order) in Melafen aqueous solutions $\left(10^{-21} \mathrm{M}\right.$ to $\left.10^{-6} \mathrm{M}\right)$. This range of Melafen concentrations is wider than that used in crop production.

Relying on the results of this work it can be inferred that microdomain structure of membranes composed of individual neutral phospholipids is changed in Melafen aqueous solutions at the wide concentration range of Melafen. At the same time, Melafen does not affect the overall structure of lipid membranes composed of a natural phospholipid mixture.

Key words: melafen, liposomes, differential microcalorimetry, small-angle X-ray scattering.
\end{abstract}

\section{Introduction}

In most cases the primary targets for biologically active substance (BAS) are the cell membranes. In connection with this fact, the actions of Melafen aqueous solutions to the structural components of membranes have been examined. Considering that Melafen is used as the plant growth regulator (it inhibits the development of seeds in large concentrations and activates it in low and ultra small) we held the complex investigation applying the aqueous solutions of Melafen over a wide range of concentrations from $10^{-21} \mathrm{M}$ up to $10^{-3} \mathrm{M}$.

It is known that the lipids are the main structural bases of membranes. In our examining for formation of model experimental objects the lipids of one of the 8 most important classes of lipids of living organisms the glycerophospholipids (the phospholipids) [5] were used. Most of phospholipid molecules consist of hydrophilic polar head with charged (or neutral) phosphate group, and hydrophobe non polar part. Thus the molecule may be neutrally or negatively charged. The hydrophobe part consists of fatty acids residues. Such architecture of phospholipid molecules permits phospholipids to form the bilayer or the hexagonal formation in water media. This fact is as the subject to stereo specific parameters and size relation of polar head and non-polar fatty acids residues. Bilayer or the hexagonal lipid structures are typical for cellular compartment, and were being discovered in vivo.

Different biologically active substances may have the significant influence on the lipid bilayer. The structure of lipid bilayer may be studied, watching changes of phase transitions of lipids and so to gain information about material localization in bilayer, and about subtle mechanisms cooperation with lipids. The phase's transitions into 
lipid membranes have been studied in details. And it is available to discover the reliable information on how the molecules localize in lipid bilayer. Localization was mirrored in lipids thermodynamic characteristics.

The lipid bilayer can exist in two main phase states - crystal ( gel L $\beta$-phase) and liquid-crystal (L $\alpha-$ phase) in temperature dependence. The bilayer transition from crystal into liquid crystalline state (and back) occurs at strictly specified temperature. Differential scanning calorimetry (DSC) determines the heat capacity dependence of lipids or membranes in suspension on temperature under constant pressure.

The low molecular weight compounds may shift the phase-transition temperature. Any causes of that phenomenon are the preferential interaction of these materials with solid or liquid states of membrane. The most of learned materials (having, for example, anesthetic activity), decrease the temperature of membrane-phase main transition. These substances connect with outer layer on the surface of membrane, primarily with liquid phase. These relationships stabilize any areas of liquid phase, and the temperature of membrane melting decreases. BAS, which are able to shift the temperature of phase-transition, increase the transition duration that are mirrored as a width of endothermic peak in the thermograms curve.

With the use of model experimental objects we managed to define any targets for influence of Melafen aqueous solution on cell membranes structure.

In our experiments the multilayered liposomes, formed from phospholipids, were used as model membranes. Thermodynamic parameters of lipids melting were determined by the DSC method in the presence of biologically active substances tested.

The method is based on the measurement of power, which was brought to cells. Cells that contained control and experimental objects are warmed up at strictly equal speed. It makes it possible to estimate the thermodynamic parameters of explored systems melting: enthalpy, temperature and half of width of main phase transition. But in diluted solutions the thermal effects, conditioned by macromolecules, are extremely small (the biopolymers heat capacity in $0.3 \%$ solution is only thousandth quota from common heat capacity of dissolvent). And only measurements by means of very sensitive differential adiabatic scanning microcalorimeter (DASM-4) [2] allowed estimating the melting parameters. The melting parameters are correlated with the structural changes in organization of lipid microdomains in bilayer in the presence of BAS.

Performance characteristics of DASM-4 [2] are: temperature range: $0-100^{\circ} \mathrm{C}$, warm-up speed $-0,2-2,0 \mathrm{grad} / \mathrm{min}$, workers volume of cells $-1,0 \mathrm{ml}$, sensibility to heat capacity $-1,6 \mathrm{x}$ $10^{-5} \mathrm{~J}_{\text {grad }^{-1}} \mathrm{ml}^{-1}$, determination accuracy of relative heat capacity $-8 \times 10^{-5} \mathrm{~J}_{g^{2}} \mathrm{~d}^{-1} \mathrm{ml}^{-1}$, record accuracy of temperature $-0,1$ grad.

The sensibility of DASM-4 is determined by three construction principles of device: differential measurement circuit, continual warmup with exactly designated speed and complete adiabatic of measuring cells. When feeding the electric current in heaters of microcalorymetry cells, these cells are heated. Simultaneously, proportionally-integrated controllers provide automatically with a high degree of accuracy the temperature equalization of thermal shields with cells temperature. The cameras happen to be in conditions, close to adiabatic, when the camera heat-exchange with environment is virtually absent. These conditions are implemented in wide temperature range when cells were heated at a constant rate [2].

The synthetic individual glycerophospholipid dimyristoylphosphatidylcholine (DMPC), was chosen in our work as the material for formation of liposomes. The hydrocarbon chains are two residues of saturated myristic acid. The molecules of DMPC have the shape of a cylinder. As the size of phosphate head is small, it is possible to form of bilayer liposomes with short crook of membrane from such phospholipid [6].

When liposomes were melted, 2 thermally induced endothermic transitions were discovered: first - pre transition and second - main transition (fig. 1 (1)).

The interpretation of calorimetric curve that describes the main transition for individual substance is the most simple. The peak, which non-clearly expressed in the area $14-15^{\circ} \mathrm{C}$, reflects the pretransition, when the restructuring ranked from order phospholipids packing (3) as "gel-phase"(6) to "ripple-phase" (4), (7). Then the main endothermic transition occurs into less rank order condition "liquid crystal" (5), (8). The "ripple-phase" presence was 


\section{ТЕХНИКО-ТЕХНОЛОГИЧЕСКИЕ ИННОВАЦИИ}

observed for certain phosphatidylcholines-membrane by electron microscopy method. In particular, it was seen that the corrugation period is different and typical for each kind of lipids. The corrugation periodicity and its quantities were changed by many factors affecting to the bilayer structure [4].

To explore the structure of bilayer membrane, composed of DMPC, the multulammelar liposomes were used fig. 1 (2). Such liposomes were formed when thin films were acted by hydration in phosphate buffer when neutral $\mathrm{pH}$ and temperature are above the phase transition. Subtle films on the walls of flask were acquired when DMPC was dried under vacuum. These multilayer films were acted by hydration consistently as - the stratum for stratum. Thus such method allowed to form the multilayer vesicular structures, composed of bilayer membranes. Obtained liposomes have the multulammelar structure sized up to 2000A from data of electron microscopy [5].

The proposed approach with aid of DSC method for inspection of properties of membranes is fairly correct. Since thermally induced phase main transition, i. e. the transition from solid - gel state in rank order to the liquid state - liquid crystal, play a major role in membranes of living organism. When liquid phase all conformational rearrangements of proteins occur easily. The oligomers formation, and the lipids flipflop moving, lateral shifting occur easily, too. In solid environment in membranes all these species of biological mobility have been hampered. And, respectively, all structural and functional activities are inhibited. The membrane structures remained, when liquid crystal state of membrane exists. And the braking of all conformation processes is lacking [4]. This is why examining of BAS action on thermally induced transitions of lipid phase is the most important link in circuit test of biological effects of BAS.

Melafen is material, applied in agriculture, as a plant growth regulator. Subject to concentrations it can operate, as the stimulator $\left(10^{-18} \mathrm{M}-10^{-13} \mathrm{M}\right)$, or as the inhibitor $\left(10^{-9} \mathrm{M}-10^{-3} \mathrm{M}\right)$ of the developments of plant seeds and body. When studying its effects on the experimental objects we used the aqueous

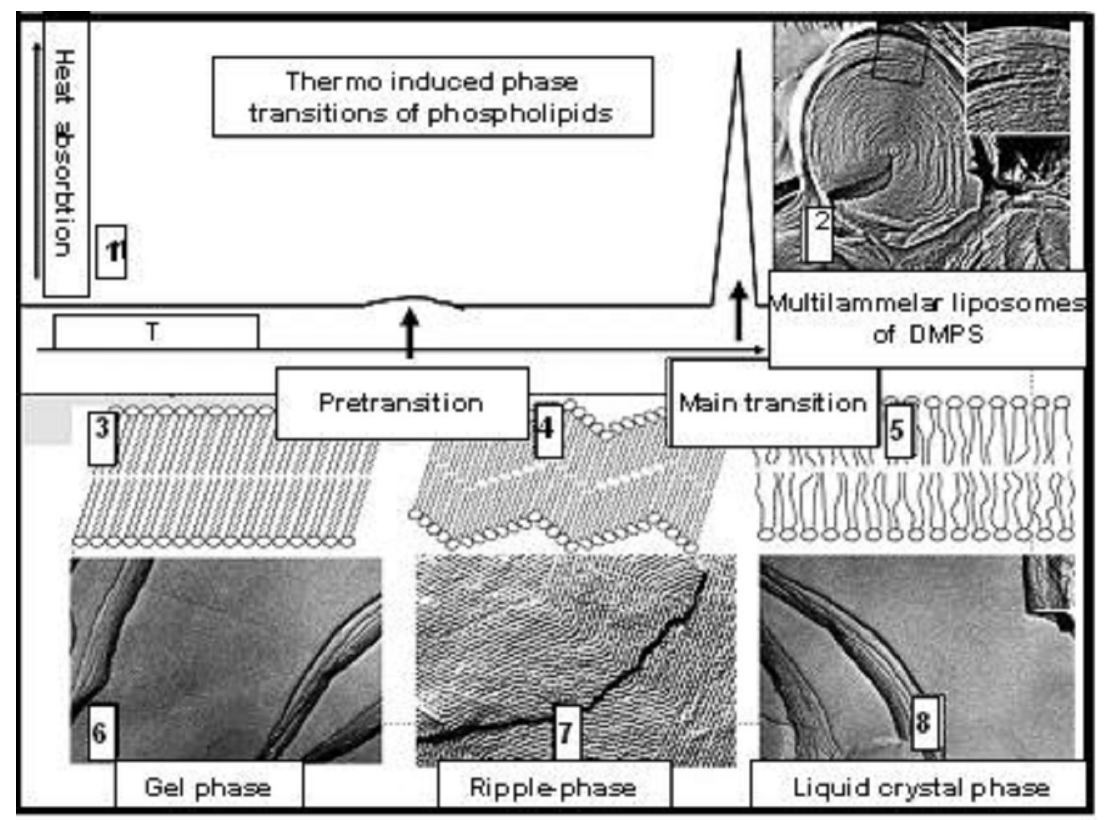

Fig. 1. Modified scheme [4] of thermally induced endothermic phase transitions of DMPC in bilayer of multulammelar liposomes when melting by the DSC method.

(1) - thermograms of endothermic phase transitions that were registered

on DASM-4 when thermally induced phase transitions of DMPC: Pre transition and main transition;

(2) - electron microscopic photo of multulammelar liposomes,

obtained by Y.S. Tarahovsky by means of crio-transmission microscopy [4];

$(3,4,5)$ - diagrams of phospholipid DMPC molecules locations when three phase states: "gel-phase" (3), "ripple-phase" (4), "liquid crystal phase" (5);

$(6,7,8)$ - electron micrographs when freeze spelling of phospholipid bilayer is able to "gel-phase" (6), "ripple-phase" (7), "liquid-crystal phase" (8) [4] 
solutions of Melafen large concentrations toultra small ones $\left(10^{-3} \mathrm{M}-10^{-21} \mathrm{M}\right)$.

Taking into account the close interdependence of vegetation and animal bodies in nature, it was necessary to study the action of plant growth regulator to objects of animal origin. As of simple model of animal cellular biomembranes, being by the primary target for biologically active substances, the phospholipid multulammelar liposomes, formed from DMPC, were used.

In the second part of this work the method of small-angle X-ray scattering (SAXS) was used. As experimental object the egg lecithin liposomes were formed.

These two methods, applied for testing of Melafen-lipids relationships with two membranes models, formed from synthetic individual phospholipid and natural mixture of egg lecithin, were used for gaining the primary aim of these investigations - evaluations of the impact of plant growth regulator on membranes of animal origin.

\section{Results and discussion}

\section{Differential scanning microcalorimety.}

In the first part of this work we investigated the action of Melafen aqueous solution under the wide range of concentrations $\left(10^{-17} \mathrm{M}-10^{-3} \mathrm{M}\right)$ to the phase state of model phospholipid membranes. Data that obtained by the DSC method, are submitted: thermodynamic parameters of liposomes DMPC melting in the presence of aqueous solutions of Melafen over a wide range of concentrations are indicated in Table. 1. The results were obtained by means of Microcal Origin 5.0 program [5].

The temperature, in which maximum heat capacity increasing of DMPC is seen for main endothermic phase transition $\left(\mathrm{T}_{\max }\right)$ occurs at $24,1-24,3{ }^{\circ} \mathrm{C}$. The Melafen aqueous solutions were added to liposomes just before melting endoterm registration. Solutions were used over a wide range of Melafen concentrations $\left(10^{-17}\right.$ $\left.\mathrm{M}-10^{-3} \mathrm{M}\right)$. Thermograms of endothermic thermally induced main transition of DMPC in the presence of aqueous solutions of Melafen when large concentrations are submitted at fig. 2. On the assumption of data, that were shown in Table 1, one can infer that Melafen in aqueous solutions when low and ultra small concentrations affected the fine structure of membranes in liposomes from DMPC. Melafen in concentrations above $10^{-17} \mathrm{M}$ enhanced the enthalpy by $1.6-8 \%$. The cooperatives of thermally induced transitions was subtracted, as demonstrated by half width increasing on half

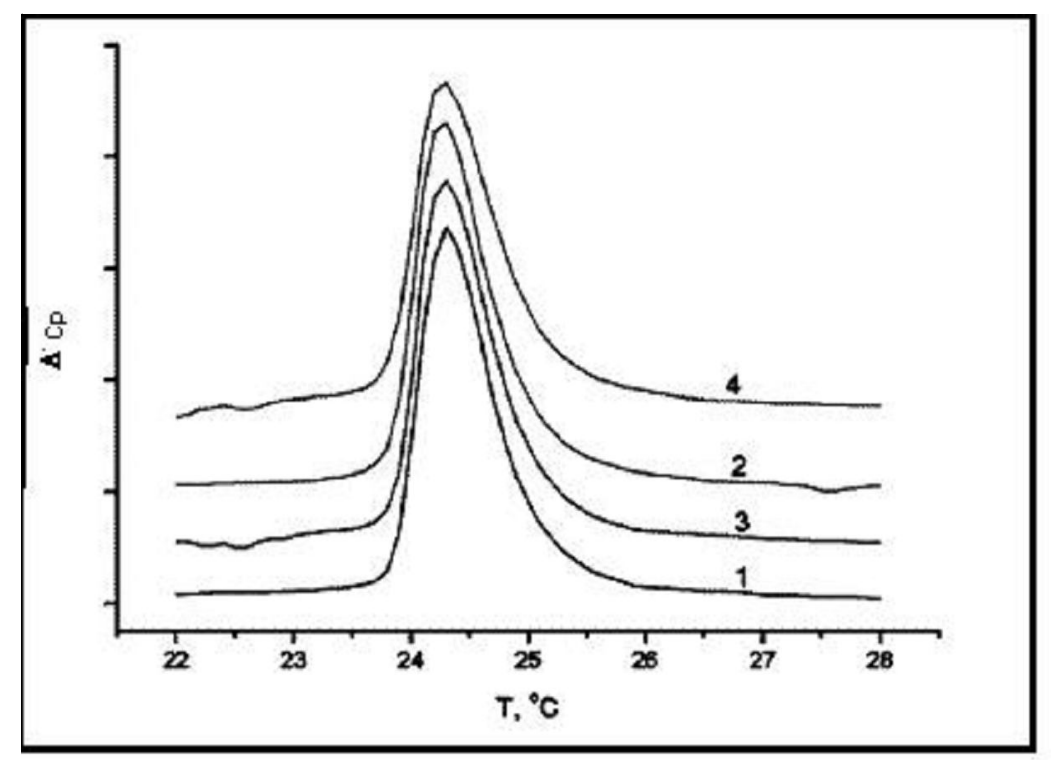

Fig. 2. The Melafen influencing to DMPC liposomes melting. The peaks of main endothermic transitions were shown. Thermograms of melting of multulammelar liposomes, formed from DMPC, and melting in the presence of large concentrations of aqueous solution of Melafen.

(1) - control 0,15 mg/ml DMPC; (2) - DMPC + 10-5 M Melafen; (3) - DMPC + 10 $0^{-3}$ M Melafen; (4) $-\mathrm{DMPC}+10^{-2} \mathrm{M}$ Melafen 


\section{ТЕХНИКО-ТЕХНОЛОГИЧЕСКИЕ ИННОВАЦИИ}

altitude transition, up to $17 \%$. And insignificantly (in limits of method accuracy) $\mathrm{T}_{\max }$ was shifted apart to higher temperatures to $0.1^{\circ} \mathrm{C}$.

The standard DSC conditions of liposomes melting had not shown any important changes for DMPC liposomes, when Melafen aqueous solution concentrations were added. $\mathrm{T}_{\max }$ of main endothermic peak, which corresponded to the thermally induced transition, was changed insignificantly. And the enthalpy and the width of transitions (the reciprocal value of the transition cooperatives) polymodal have undergone changes.

As a next step of investigation of Melafen influencing on DMPC liposomes we carried out the experimental model study with the special modification. In order to reduce the Melafen solution actions to the phospholipid membrane structures the specific approach of different speed of heat supplied (1 degree/min has been used; 0,5 degree/min; 0,25 degree/min; 0,125 degree/ $\mathrm{min}$ ) to cells with control and experimental samples was used by us. Such approach use in order to educe some eventual restructuring of additive cooperative units in membrane microdomains.

From data of thermograms registered at different melting rates of membranes, the concentration dependences of melting enthalpy have been built (the data are introduced on fig. 3).

Table 1

Effect of Melafen aqueous solutions under various concentrations on parameters of thermally induced endothermic DMPC main phase transition

\begin{tabular}{|c|c|c|c|}
\hline $\begin{array}{c}\text { Melafen concentration in } \\
\text { DMPC suspension (M) }\end{array}$ & $\mathrm{T}_{\max }\left(\mathrm{C}^{\circ}\right)$ & $\begin{array}{c}\text { Cooperativity of main } \\
\text { transition (arb.un.) }\end{array}$ & $\begin{array}{c}\text { Enthalpy of main } \\
\text { transition (arb.un.) }\end{array}$ \\
\hline Without Melafen & 24.1 & 0.6 & 358.1 \\
\hline $10^{-21} \mathrm{M}$ & 24.1 & 0.7 & 351.3 \\
\hline $10^{-19} \mathrm{M}$ & 24.1 & 0.7 & 347.1 \\
\hline $10^{-17} \mathrm{M}$ & 24.2 & 0.7 & 363.9 \\
\hline $10^{-15} \mathrm{M}$ & 24.2 & 0.6 & 379.5 \\
\hline $10^{-13} \mathrm{M}$ & 24.2 & 0.6 & 370.1 \\
\hline $10^{-11} \mathrm{M}$ & 24.2 & 0.7 & 375.2 \\
\hline $10^{-7} \mathrm{M}$ & 24.2 & 0.7 & 366.4 \\
\hline $10^{-5} \mathrm{M}$ & 24.2 & 0.7 & 372.6 \\
\hline $10^{-3} \mathrm{M}$ & 24.2 & 0.8 & 385.4 \\
\hline
\end{tabular}

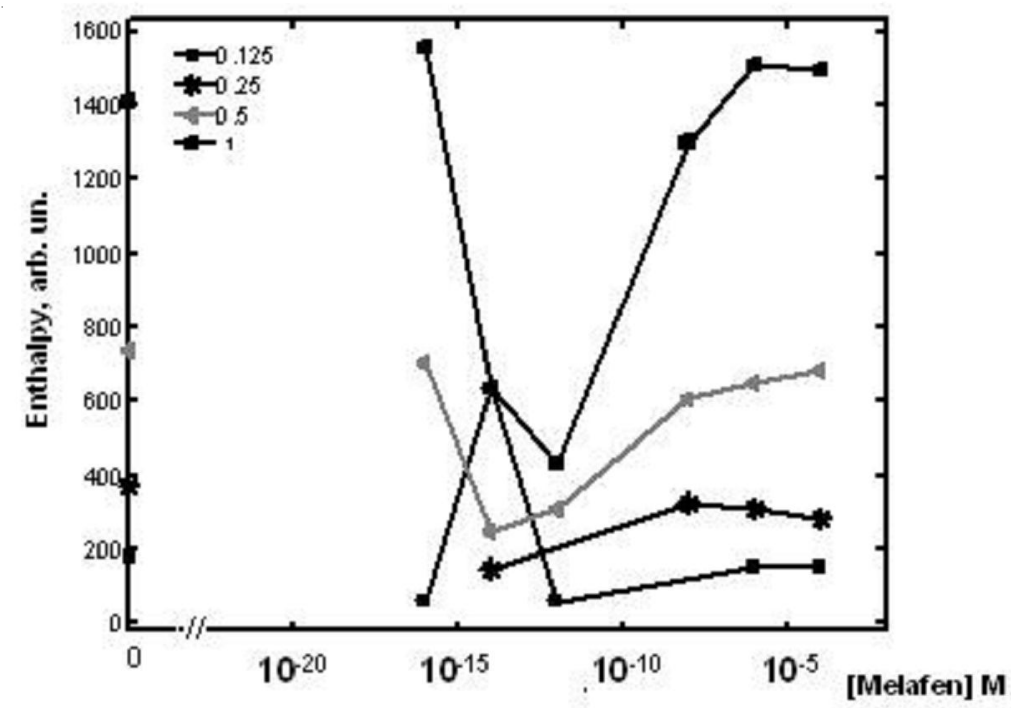

Fig. 3. The of Melafen aqueous solutions with various concentrations effect to enthalpy of main thermally induced DMPC transition when different speeds of heat supplied to DSC cells with control and experimental samples. Different speed of heat supplied (1 degree/min has been used; 0,5 degree $/ \mathrm{min} ; 0,25$ degree $/ \mathrm{min}$;

$0,125 \mathrm{degree} / \mathrm{min}$ ) to cells with control and experimental samples. (Melafen concentration was given in logarithmic scale. The point 0 was conditional.) 
$\mathrm{T}_{\max }$ and the half widths on half altitude of main transition under the wide range of the Melafen concentration strongly marked the extreme, which have been observed in the area of Melafen concentrations $10^{-14} \mathrm{M}-10^{-10} \mathrm{M}$, when all examined melting rates (data were not shown). The extremes and dose-depending of $\mathrm{T}_{\max }$ and half width on half altitude of transition were appeared in the same Melafen concentration range, when such method was applied for DMPC liposomes melting.

It is known that the deceleration of heat supply to cells with control and experimental samples changed the parameter of thermally induced transitions. Evidently, the relaxation processes in bilayer of phospholipid membranes were different. Indeed, in control samples the changes have been noted, too. The deceleration of heat supplied to cells considerably reduces the main phase-transition $\mathrm{T}_{\text {max }}$ and the enthalpy, but the cooperatives were changed insignificantly. The complex polymodal picture of action of Melafen solutions in large and medium concentrations, was found. It should be noted that enthalpy changes were great in control samples in ultra small $10^{-17}$ $\mathrm{M}, 10^{-16} \mathrm{M}$ and large $10^{-6} \mathrm{M}, 10^{-5} \mathrm{M}$ of Melafen concentrations (fig 3). Melafen concentration 10 ${ }^{13} \mathrm{M}, 10^{-12} \mathrm{M}$ "hindered" the enthalpy change. And for changing $\mathrm{T}_{\text {max }}$ and for width of transitions the same regularity was observed.

So, it has been ascertained that additions of Melafen aqueous solutions to DMPC liposomes exerted the significant complex dose-dependence effects on lipid bilayer structure. It should be noted that Melafen - the hydrophilic substance, deprived of any possibility to be incorporated into lipid bilayer. However, it is known that when bilayer melts the growth of membrane permeability is observed. This phenomenon may be linked with the processes of short-lived nana-size pours forming [6]. The bilayer melting was held at physiologically appropriate temperatures.

As the multulamellar liposomes have defects of bilayer, and some pores, which are permeable for water [ibid.], it can be assumed that Melafen aqueous solutions operate to all liposomes in multilayer. However, all of Melafen effects may take place only on the surface of each bilayer. Evidently, Melafen may act or as transducer of water structures near the surface of bilayer, or it directly influences on DMPC phospholipid heads. It was disclosed that in concentration range $10^{-14} \mathrm{M}-10^{-10} \mathrm{M}$ Melafen exerts the maximum impact on thermally induced transitions parameters: temperature, in which maximum of heat capacity increase is seen $\left(\mathrm{T}_{\text {max }}\right)$, enthalpy and cooperatives. Data obtained from model membranes and biomembranes, once again indicated that the affect may be determined by formation in water media the supramolecular complexes Melafen -aqueous in vitro [7].

As it was mentioned above, low and ultra small Melafen concentrations do not exert destructive action on model membranes that are formed from individual neutral phospholipid. But restructuring the lipid microdomains in bilayer occurr. Large, middle and ultra small Melafen concentration changed the intra membranous organization - microdomains structures of lipids in liposomes formed from individual neutral phospholipid. The polymodal changes of dosedependent parameters of thermally induced transition may take place due to certain relaxation conditions of structural elements of bilayer by means of certain changes of melting rates. The experimental model objects that were formed from individual neutral phospholipid DMPC, are more vulnerable to Melafen actions compared to liposomes that were composed of neutral and charged phospholipids. Mixtures simulate the nature of stable membranes. Precise equilibrium distribution of phospholipids provides the bilayer stability. For example, it is known that the destruction of plasma membrane of cells in case of their death - apoptosis is associated with the phospholipids redistribution. So when apoptosis, in starting equable on charges and topography of native membrane occurs, the phosphatidylserine moves to the exterior leaf of bilayer. This phosphatidylserine moving causes the charge destabilization and leads to destroying the packing regularity in bilayer. The structure breaks down, that was followed by membrane fragmentation, and the cell death comes [8].

That is why the following part of our work is devoted to the study of the effect of Melafen aqueous solutions over a wide range of concentrations to the structural organization of lipids in membranes that were composed from mixture of nature phospholipids. The multulammelar liposomes formed from egg lecithin were used as experimental objects. Such multulamellar liposomes formed from egg lecithin 
are the convenient model, which may be approximated compositionally and structurally to nature membranes.

The locations of membranes change in the cell interior due to cellular life activity. Some membranes are coming together. The structures of most membrane are sequenced or become disordered, or removed. The biologically active substances actions may be lacking the certain target of its effects. However, so much of BAS touch the whole processes. It may influence the structural orders of different organizational levels from the regularity degree of membranes and bilayer thickness up to reciprocal locations of bilayer.

The election of egg lecithin for exploration of Melafen action on membranes, which are composed of nature phospholipids, had been conditioned by the following reasons. The egg lecithin primarily contains phosphatidylcholine and phosphatidylethanolamine, but so less it contains phosphatidylinositol and fingocholine. To the composition of these phospholipids molecules the polar groups are entering: choline, ethanolamine, and inositol. And fatty acids residues of different quantity and degree of saturation are contained in these molecules. These phospholipids are kept in all cell membranes of animal origin. It composes the basis of structural ensuring of the membranes integrity. And phospholipids as well support the membrane components functional activity. For active works of integrated and associated membrane proteins (receptors, channels, ionic exchangers, pumps and enzymes) the certain environment compositions near these proteins are necessary. For maintaining of integrated and associated membrane proteins activity the certain types of annular lipids are so important. The proteins primarily interact with zwitterionic lipid phosphatidylcholine. Its molecule in general is electro neutral, since it carries both positive and negative charges.

The fluidity of membrane lipid phase can control the protein conformation fluctuations, which are required for maintaining the corresponding protein activity. Membrane thickness was conditioned by the length of fatty acids residues and sizes of phospholipid heads in phospholipids molecules. Membrane thickness permits to control the intensity of function of proteins that are built into membrane. For example, the large integral protein $-\mathrm{Ca}^{2+}$-ATPase (from family of SERCA2) changes its affinity for ligands in dependence of membrane thickness. So, the operating of depth or outcropping of membranous loops with ligands-binding centers regulates the work activity of this $\mathrm{Ca}^{2+}$-pump. $\mathrm{Ca}^{2+}$-ATPase of sarcoplasmic reticulum (the main $\mathrm{Ca}^{2+}$-store in muscle cells) is surrounded by the phosphatidylethanolamine, witch has the cone molecular shape. This type of molecular structure allows the lipids molecules to form the hexagonal phase. For example, associated proteins - G-proteins, which are linked and implanted in membrane, are surrounded by phosphatidylethanolamine, too [9]. G-proteins conduct the signals from receptors located in the outer surface of plasmalemma to cytoplasm enzymes. Their activities are in great dependence on lipid environment.

In connection with enumerated arguments, we separated the phospholipid models for test action of biologically active substance as experimental models, which are fairly actuating for many cell structural and functional parameters.

Above it was seen that DSC method, which was based on different heating rate of cell with experimental sample of liposomes DMPC, brought to light to the significant influences of Melafen aqueous solution (over a wide range of concentrations) on organization of lipid microdomains in bilayer. The 3 parameters of thermally induced endothermic main transitions of DMPC were registered by us. It was testified that the microdomains organization of phospholipid in bilayer was in subject to Melafen concentration.

It was known that Melafen is the hydrophilic molecule. But we noted that it action extends to all thickness of multulammelar liposomes. Since the peak of main transition remain clearly discovered. In visible, Melafen enters via defects of bilayer. It is possible to form the nana-pores during phase transitions also. Melafen action shall be exercised on hydrophilic surface of each bilayer. It can be assumed that Melafen changes the water medium around liposomes. It either forms the supramolecular complexes of Melafen-aqua, or it changes the gas solubility in the water solution.

However, in liposomes formed from the egg lecithin, i.e. from the natural phospholipids mixture, we could not measure the parameters of microdomain organization of lipid bilayer by the DSC method correctly because the heat 
capacity peaks for each phospholipid in such mixture were overlapped. Due to this fact we did not get any clear picture suitable for quantitative parameter estimation of thermally induced transitions in the egg lecithin membranes. This is why we investigated the structural changes of lipid membranes, composed of natural phospholipids mixture, under the action of Melafen with the aid of another method, namely by the small-angle $\mathrm{X}$ ray scattering technique. Thus, we have studied the next more complicated level of membrane structural organization in multilammelar liposomes.

\section{Small-angle $X$-ray scattering.}

At the second part of this work the action of Melafen on the structure of phospholipid membranes in multilayer liposomes was studied by one of the methods of X-ray diffraction analysis, namely by small-angle X-ray scattering (SAXS) [10]. This method permits one on the basis of the analysis of the measured SAXS intensity to get information about lowresolution structure of lipid membranes and to characterize membrane stacking parameters in liposomes.

The SAXS study of liposomes was carried out with an automated small-angle X-ray diffractometer assembled in the Institute of Biochemical Physics RAS. This diffractometer was developed on the basis of the construction of the small-angle X-ray diffractometer AMUR-K elaborated and exploited earlier in the Institute of Crystallography RAS.

Because the diffractometer used in this study is a custom-built device a general description of its construction is given hereinafter.

The X-ray source in this diffractometer is an X-ray generator IRIS-M (Nauch-Pribor, Orel, Russia) with a fine focus X-ray tube with a copper anode BSV29Cu (Svetlana-Roentgen, St. Petersburg, Russia). The X-ray beam passes through a Ni $\beta$-filter, and then is focused with a glass mirror and collimated with tantalum slits. A sample for SAXS study (liposome suspension) is placed in a thin-walled (wall thickness $\sim 10 \mu \mathrm{m}$ ) glass capillary of $\sim 1 \mathrm{~mm}$ outer diameter (sample volume $\sim 15 \mu 1$ ).

SAXS patterns are recorded with the gasfilled ( $85 \% \mathrm{Xe}, 15 \% \mathrm{Me}, 4 \mathrm{~atm})$ linear position- sensitive detector constructed in the Joint Institute for Nuclear Research (Dubna, Russia) [11]. The detector has 1024 channels of discretization, the width of each channel is 97 micrometers. For CuKб X-ray radiation $\left(\lambda_{\text {avr }}=0.1542 \mathrm{~nm}\right)$ the detector has the special resolution of $150-200$ micrometers and the efficiency of registration about $75 \%$. SAXS patterns recorded with the detector are transferred to a personal computer for storage and processing.

For an X-ray tube with a copper anode and sample-to-detector distances from 130 to $425 \mathrm{~mm}$ accessible in the diffractometer it is possible to record the intensity of X-ray scattering in the range of the values of diffraction vector module $S=$ $(2 \sin \theta) / \lambda$ from $\sim 0.015 \mathrm{~nm}$ to $\sim 3.5 \mathrm{~nm}^{-1}$ ( $\lambda$ is the wavelength of $\mathrm{X}$-radiation, $\theta$ is a half of a scattering angle). This range of $S$ values corresponds to the range of Wolf-Bragg distances $D=(S)^{-1}$ from $\sim 67 \mathrm{~nm}$ to $\sim 0.286 \mathrm{~nm}$.

Due to the X-ray beam focusing with a mirror and simultaneous registration of X-ray diffraction pattern with a position-sensitive detector a high intensity of X-ray scattering and high sensitivity of registration are achieved in such a diffractometer. This is very important for efficient SAXS study of liposomes and other biologic objects which have labile structure and scatter X-rays rather poorly.

Multilayered liposomes for SAXS study were formed by the method of hydration of lipid films. At first the egg lecithin (Sigma, USA) was dissolved in chloroform in a glass flask. Then chloroform was evaporated from this solution under argon gas flow and a thin lipid film was formed on the walls of the flask. For a complete removal of chloroform from a lipid film it was kept under vacuum not less than 12 hours. After this a small amount of buffer solution $(50 \mathrm{mM}$ phosphate buffer, $\mathrm{pH} 7.5,200 \mathrm{mM}$ of $\mathrm{NaCl}$ ) was poured in the flask with a lipid film, the flask was filled with argon gas, heated up to $\sim 45^{\circ} \mathrm{C}$ and then was vigorously shaken with an electric shaker until a lipid film was totally dispersed in the buffer solution. The lipid concentration in liposome suspensions used in SAXS study was about $10 \%$. Melafen was dissolved in the same buffer solution and was added to liposome suspensions at $\sim 25^{\circ} \mathrm{C}$ in quantities required to achieve Melafen concentration in these suspensions equal to $10^{-21} \mathrm{M}, 10^{-18} \mathrm{M}, 10^{-2} \mathrm{M}$ 
and $10^{-6} \mathrm{M}$. Prepared liposome suspensions with Melafen were stored in closed vials under argon gas at a temperature of $\sim 5^{\circ} \mathrm{C}$ before being used in the SAXS study.

The SAXS study of liposome suspensions was done at the ambient room temperature $\left(\sim 22{ }^{\circ} \mathrm{C}\right)$. The duration of the SAXS intensity measurement for each liposome specimen was 30-50 min.

For background scattering correction the SAXS intensity of the capillary with buffer solution was measured and then subtracted from the SAXS intensity measured for each liposome sample. To take account of lipid concentration variation in liposome samples arising from addition of Melafen solutions in liposome dispersion the SAXS intensity for all samples was normalized to have the equal peak intensity at $S \approx 0.14 \mathrm{~nm}^{-1}$. SAXS patterns smoothing and desmearing with method [12] were done with PRO software developed in the Institute of Crystallography RAS (SAXS patterns smearing is intrinsic for diffractometers with slit collimation systems).

SAXS patterns for all liposome samples studied (liposome suspensions containing $10^{-21} \mathrm{M}$, $10^{-18} \mathrm{M}, 10^{-12} \mathrm{M}, 10^{-6} \mathrm{M}$ of Melafen and without Melafen) disclose two diffraction peaks (reflections) with maxima at $S \approx$ $0.14 \mathrm{~nm}^{-1}$ and $S \approx 0.29 \mathrm{~nm}^{-1}$. As an example, two experimental SAXS patterns of liposome suspensions containing $10^{-6} \mathrm{mM}$ of Melafen and without Melafen are shown in fig. 4a. In these patterns (fig. 4a) background scattering was subtracted and intensities were normalized. The same SAXS patterns after smoothing and collimation correction are submitted in fig. $4 \mathrm{~b}$.

The X-ray diffraction peaks on the SAXS patterns for all studied liposome suspensions were equidistant (the abscissa of the second peak is approximately twice the abscissa of the first peak). Consequently, these diffraction peaks can be considered as the first and the second orders of reflection for membrane multilayers in liposomes (lipid lamellar phase).

The normalized SAXS intensities for all liposome samples studied (liposome suspensions containing Melafen and control suspensions without Melafen) were very similar, as illustrated for two samples of liposome suspensions containing $10^{-6} \mathrm{mM}$ of Melafen and without Melafen in figs. $4 \mathrm{a}$ and $4 \mathrm{~b}$.

This indicates that the structure of lipid membranes and their stacking parameters in liposomes are not noticeably altered by Melafen addition to liposome suspension.

The period $D$ of membrane stacking in liposomes was calculated for liposome samples after collimation correction according to the WolfBragg formula as $D=h\left(S_{h}\right)^{-1}$. In this formula $h$ is the order of reflection and $S_{h}$ is the abscissa of this reflection determined as the value of $S$ at which the first derivative of SAXS intensity goes to zero.

Results obtained showed that the values of period $D$ of membrane stacking in liposomes at all studied Melafen concentrations and in liposomes without Melafen were the same with the accuracy $\pm 0.01 \mathrm{~nm}$ (tab. 2). Such accuracy does not exceed the experimental error. So we can state that within experimental error of the SAXS method Melafen when concentrations $10^{-21} \mathrm{M}, 10^{-18} \mathrm{M}, 10^{-12} \mathrm{M}$ and $10^{-6} \mathrm{M}$ has no influence on membrane stacking period in multilammelar liposomes formed from the egg lecithin.

Table 2

\section{Lipid membranes stacking period $D$ in liposomes in various Melafen concentrations in buffer solution. The values of $D$ were calculated after collimation correction of SAXS patterns and for each pattern were averaged on two orders of diffraction}

\begin{tabular}{|c|c|}
\hline Melafen concentrations & $D, \mathrm{~nm}$ \\
\hline Without Melafen (control №1) & 6.88 \\
\hline $10^{-21} \mathrm{M}$ & 6.89 \\
\hline $10^{-18} \mathrm{M}$ & 6.88 \\
\hline $10^{-12} \mathrm{M}$ & 6.88 \\
\hline $10^{-6} \mathrm{M}$ & 6.88 \\
\hline Without Melafen (control № 2) & 6.90 \\
\hline
\end{tabular}

The widths of corresponding diffraction peaks were also one and the same for all liposome suspensions studied as illustrated for two samples in figs. $4 \mathrm{a}$ and $4 \mathrm{~b}$. This is the evidence for the same size of the regions of coherent scattering and the same degree of membrane stacking order in these regions for membrane multilayers in liposome suspensions 


\section{ТЕХНИКО-ТЕХНОЛОГИЧЕСКИЕ ИННОВАЦИИ}

containing $10^{-21} \mathrm{M}, 10^{-18} \mathrm{M}, 10^{-12} \mathrm{M}, 10^{-6} \mathrm{M}$ of Melafen and in liposome suspensions without Melafen.

For further analysis of Melafen action on lipid membrane structure in liposomes the electron density profiles of these membranes when various concentrations of Melafen in buffer solution were calculated on the basis of the SAXS data.
One-dimensional centrosymmetric electron density profiles $c(x)$ of membrane multilayers in liposomes were calculated at the relative scale in the normal direction to membrane planes by means of Fourier transformation of collimation corrected SAXS patterns utilizing the formula:

$$
\rho(x)=2 / D \sum_{h=1}^{N} P(h) h \sqrt{I(h)} \cos \left(\frac{2 \pi h x}{D}\right),
$$
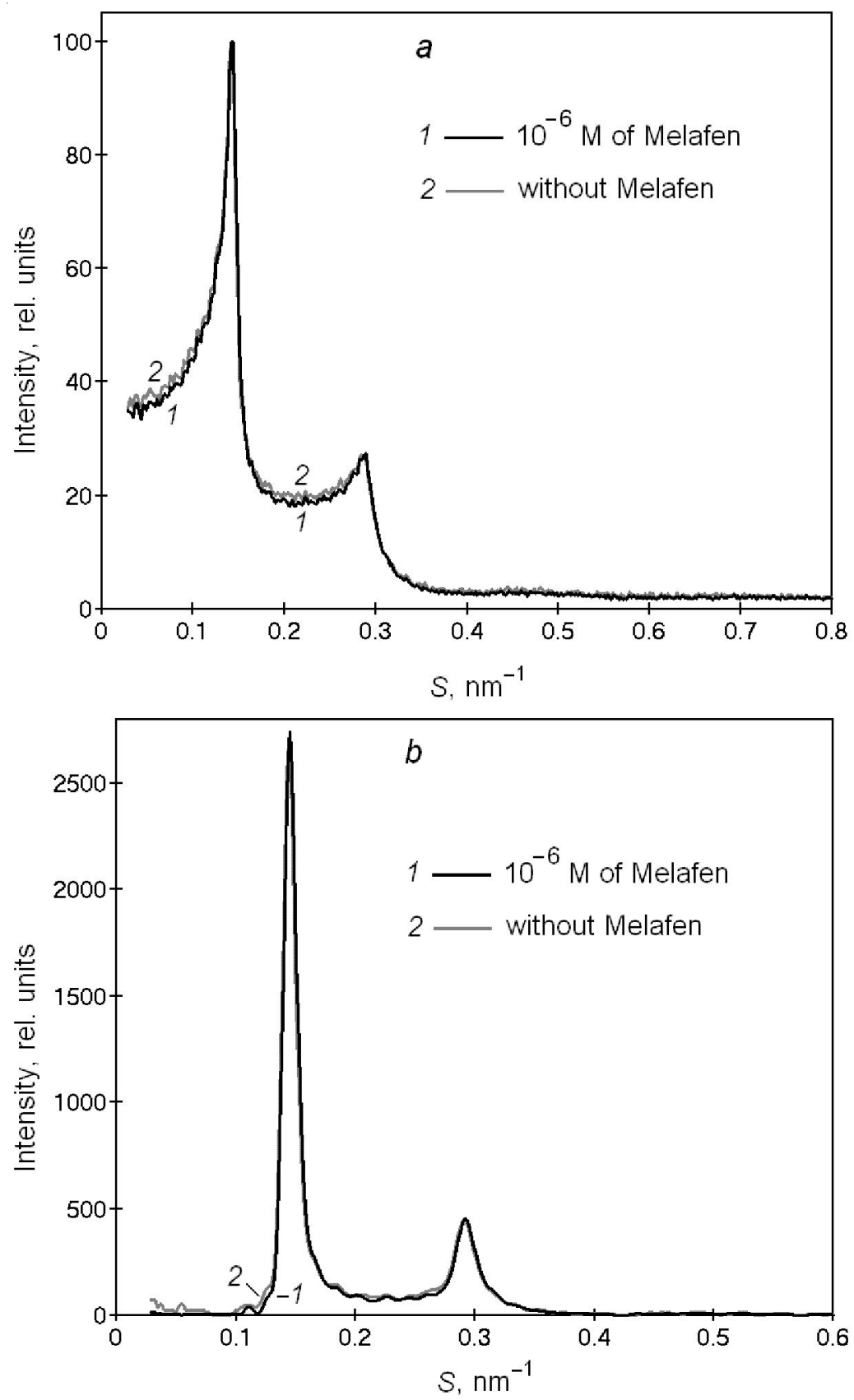

Fig. 4. SAXS patterns of liposome suspension containing $10^{-6} \mathrm{M}$ of Melafen (1) and liposome suspension without Melafen (2): $a$ - experimental SAXS patterns after subtraction of background scattering and intensity normalization, $b$ - the same SAXS patterns after smoothing and collimation correction. $S=(2 \sin \theta) / \lambda$ 
In this formula $D$ is a stacking period of membranes in liposomes, $h$ is an order of reflection (in our case this is a number of a diffraction maximum), $P(h)$ is a phase sign (+ or -) for the $h$ order reflection, $I(h)$ is the integrated intensity of the $h$ order reflection, $N$ is a maximum order of reflections (in our case $N=2$ ). The multiplier $h$ in formula (1) is the intensity correction factor for membrane multilayers disorientation in liposome suspension (Lorenz factor).

The electron density profiles of lipid membranes were calculated using the formula (1) and utilizing SAXS patterns depicted in fig. $4 \mathrm{~b}$ for liposome suspensions containing $10^{-6} \mathrm{M}$ of Melafen and without Melafen are shown in fig. 5

The peaks of the electron density on these profiles at $x \approx 1.4 \mathrm{~nm}$ and $x \approx 5.4 \mathrm{~nm}$ can be associated with the position of lipid polar groups in a lipid bilayer, and the electron density minimum at $x \approx 3.4 \mathrm{~nm}$ corresponds to the central hydrophobic part of a lipid bilayer. The thickness of lipid membrane is defined as the distance between the peaks of the electron density at $x \approx 1.4 \mathrm{~nm}$ and $x \approx 5.4 \mathrm{~nm}$ is about $4 \mathrm{~nm}$. As is seen from fig 5 , the electron density profiles of lipid membranes for liposome suspensions containing $10^{-6} \mathrm{M}$ of Melafen and without Melafen are identical. The same electron density profiles of lipid membranes were obtained when Melafen concentrations in buffer solution equal to $10^{-21} \mathrm{M}, 10^{-18} \mathrm{M}$ and $10^{-2} \mathrm{M}$.

So, the results of the SAXS study of liposome suspensions show that Melafen, which presents in wide concentration range (from $10^{-21} \mathrm{M}$ up to $10^{-6} \mathrm{M}$ ), has no visible effect on the structure and stacking parameters of phospholipid membranes in multilayered liposomes formed from egg lecithin. The absence of destructive changes of phospholipid membranes in the presence of Melafen in solution may be considered as a positive factor for practical applications of this biologically active substance.

\section{Conclusion}

These investigations are important because the cell membranes are the primary targets for exogenous operative factors (biologically active substances at our case) entering into animal body by all ways. Lipids are the major and prevailing

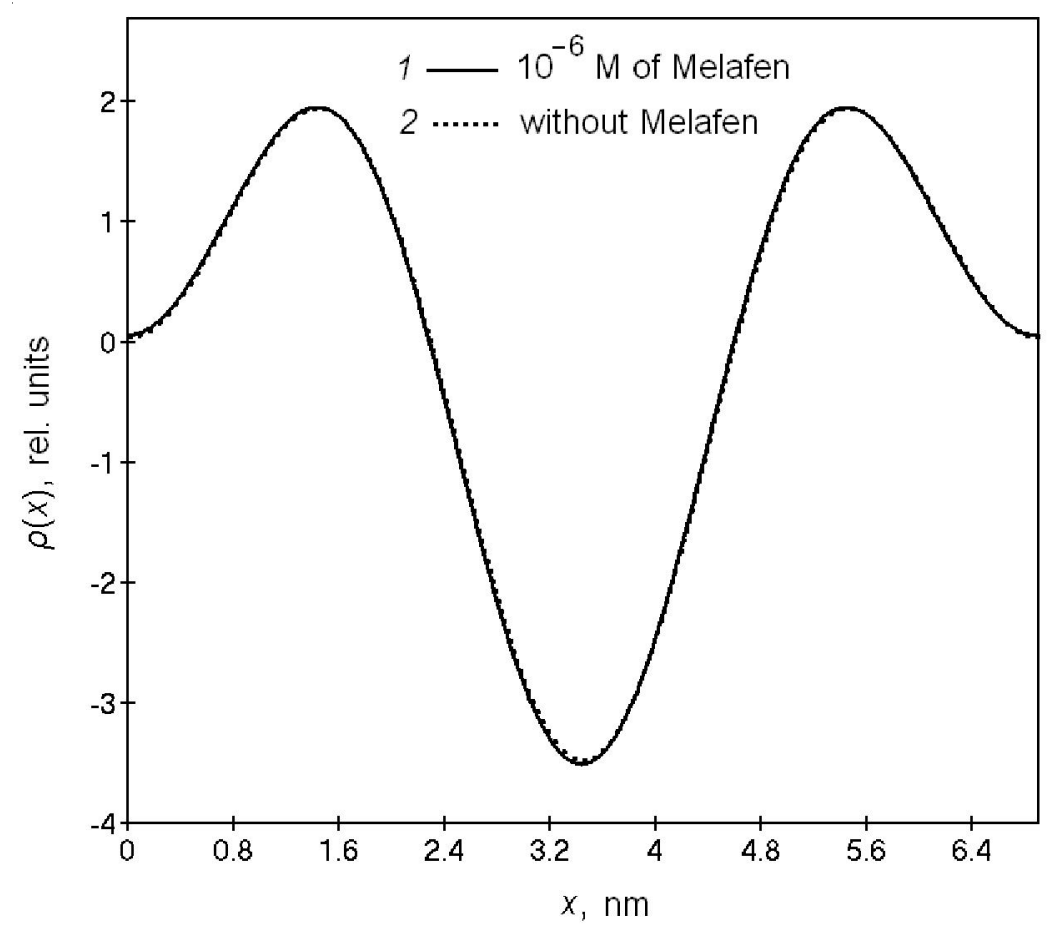

Fig.5. Electron density profiles of phospholipid membranes in multulammelar liposomes formed from egg lecithin: 1 - for liposome suspension containing $10^{-6} \mathrm{M}$ of Melafen; 2 - for liposome suspension without Melafen ( $x$ is a distance in the direction normal to membrane planes) 
components of the animal cellular membranes. This is why phospholipids were chosen for our investigations, as the most widespread components of membrane lipid phase. For differential scanning calorimetric testing of membrane structural properties the synthetic individual neutral phospholipid DMPC was used. When melting, DMPC multilammelar liposomes have simple thermograms with two phase endothermic transitions in physiological temperature range. These thermograms are interpreted easily. Pretransition and the main phase transition in the presence of biologically active substances changed its parameters (enthalpy, $\mathrm{T}_{\max }$ and cooperativity of the main phase transition). Our formulation of experiment was complicated by the special modification. This modification consisted in four different speeds of heat supplied to DSC cells, which contained control and experimental samples. This type of model study is fairly physiological because restructurings of lipid phase in membranes take place in animal organism constantly. In certain cases (for instance, when hibernation) membrane restructurings are temperature-dependent. And the rates of temperature changing are different sometimes also.

For experiments with the aid of the smallangle X-ray scattering method the multulamellar liposomes formed from a natural phospholipid mixture were used. The multulamellar liposomes formed from egg lecithin are a difficult object for differential scanning calorimetric test. The phospholipid mixture gives the confluent peaks of heat capacity and the estimation of calorimetric parameters by deconvolution procedure does not allow correct deciphering of the biologically active substances effect on the certain lipid microdomains. This is why we studied by the SAXS technique the next organizational level of lipid membranes - the lamellar structure and mutual arrangement of lipid membranes in multilayer liposomes.

We did not reveal by the SAXS method any noticeable structural changes of the egg lecithin membranes at Melafen concentrations used for a crop production. The SAXS method disclosed that the bilayer organization of multulammelar liposomes formed from egg lecithin was not changed in the presence of Melafen.

But on the base of differential scanning microcalorymetry data we discovered that the microdomain structure organization of DMPC liposome membrane was changed by Melafen aqueous solutions in the wide concentration range. The types of these variations were rather complex.

We concluded that Melafen changed the microdomain organization of structure in membrane formed from individual neutral phospholipid and did not affect the membrane structure at the next organizational level. Namely Melafen did not change the overall size and spacing of bilayers in multulammelar liposomes formed from natural phospholipid mixture. These results were reported shortly elsewhere [13].

However, we should indicate that the aqueous solutions of Melafen altered the structural properties of labile objects which can easily change their conformation. Such influence was shown for objects related not to plant life, but to animal life, namely for liposomes formed from individual phospholipid [13] and for the water soluble protein (bovine serum albumin) [14]. As membrane composition becomes more complicated, the membrane structure becomes more resistant to the bed environment (or biologically active substances as in our case). These phenomena in our works were shown for liposomes formed from a mixture of natural phospholipids and for erythrocyte ghost [15]. The aqueous solutions of Melafen did not influence on these objects. However, when experimental object acquired any functions, the structure of this object began to be exposed to Melafen influence. In this case the alteration of structural parameters of the model object under the action of biologically active substances may be mediated by the influence of these substances on some functions of this object.

As an example of this phenomenon one can mention the shape changing of erythrocytes [16]. The aqueous solutions of Melafen exert significant influence on cell function. The purine-dependent calcium signaling in insulated thymocytes, lymphocytes and cells of ascetic Ehrlich carcinoma decreased to the complete oppression when large concentrations of Melafen [17].

The main finding following from all our studies [13-17] is the necessity of very strict observance of concentration limitations of Melafen when it will use as the plant growth regulator. This is vitally important for the prevention of Melafen negative influence on bodies of animal origin. 


\section{REFERENCES}

1. Albantova A.A., Binyukov V.I., Alekseeva O.M., Mill E.M. The Investigation of Influence of Phenozan, ICHPHAN-10 on the Erythrocytes in vivo by AFM Method. Varfolomeev S.D., Burlakova E.B., Popov A.A., Zaikov G.E., eds. Modern Problems in Biochemical Physics Horizons. New York, Nova Science Publishers, 2012, chapter 5, pp. 45-48.

2. Alekseeva O.M. The Influence of Melafen Plant Growth Regulator, to Some Metabolic Pathways of Animal Cells. Polymers Research Journal, 2013, vol. 7, no. 1, chapter 6, pp. 15-23.

3. Alekseeva O.M., Fatkullina L.D., Kim Yu.A., Zaikov G.E. The Melafen Influence on the Erythrocyte's Proteins and Lipids. Herald of Kazan Technological University, 2014, vol. 17, iss. 9, pp. 176181. (in Russian).

4. Alekseeva O.M., Kim Yu.A., Zaikov G.E. The Interactions of Melafen and Ihfans With Animal's Soluble Protein. Herald of Kazan Technological University, 2014, vol. 17, iss. 7, pp. 164-167. (in Russian).

5. Alekseeva O.M., Krivandin A.V., Shatalova O.V., Rikov V.A., Fattacfov C-G.G., Burlakova E.B., Konovalov A.I. A Study of Melafen Interaction With Phospholipid Membranes. Reports on Biochemistry and Biophysics, 2009, vol. 427, pp. 218-220.

6. Antonov V.F., Smirnova E.Yu., Shevchenko E.V. Lipid Membrane in Phase Transformations. Moscow, Nauka Publ., 1992, p.125.

7. Cheremukina G.A., Chernenko S.P., Ivanov A.B., Pashekhonov V.D., Smykov L.P., Zanevsky Yu.V. Automatized One-Dimensional X-Ray Detector. Isotopenpraxis, 1990, vol. 26, pp. 547-549.

8. Escriba P.V., Ozaita A., Ribas C., Miralles A., Fodor E., Farkas T., Garcia-Sevilla J.A. Role of Lipid Polymorphism in G Protein-Membrane Interactions: Nonlamellar-Prone Phospholipids and Peripheral Protein Binding to Membranes. Proc. Natl. Acad. Sci. U.S.A., 1997, vol. 94, pp. 11375-11380.
9. Fahy E., Subramaniam S., Brown H.A., Glass C.K., Merill A.H., Jr., Murphy R.C., Raetz C.R., Russell D.W., Seyama Y., Shaw W., Shimizu T., Spener F., van Meer G., Van Nieuwenhze M.S., White S., Witztum J.L., Dennis E.A. A Comprehensive Classification System for Lipids. J. Lipid Res., 2005, vol. 46, pp. 839-861.

10. Feigin L.A., Svergun D.I. Structure Analysis by Small-Angle X-Ray and Neutron Scattering. New York, Plenum Press, 1987.

11. Hampton M.B., Vanags D.M., Porn-Ares M.I., Orrenius S. Involvement of Extracellular Calcium in Phosphatidylserine Exposure During Apoptosis. FEBS Lett., 1996, vol. 399, pp. 277-282.

12. Konovalov A.I., Rigkina I.S., Fattachov S-G.G. Supramolecular Structure-Based on Hydrophilic Derivative of Melamine and Bis (Hydroxymethyl) Phosphinic Acid (Melafen) and Surface-Active Substance. Message 1. Structure and Melafen SelfAssociation in Water and Chloroform. Reports of Academy of Science. Series Chemical, 2008, no. 6, pp. 1207-1214.

13. Privalov P.L., Plotnikov V.V. Three Generations of Scanning Microcalorimeters for Liquids. Therm. Acta., 1989, vol. 139, pp. 257-277.

14. Shedrin B.M., Feigin L.A. Collimation Correction for Small-Angle X-ray Scattering. The Case of Final Dimensions of Slits. Crystallographia, 1966, vol. 11, pp. 159-163 (in Russian).

15. Tharahovsky Y.S. Intellectual Lipid NanoContainers in Address Delivery of Drug Substances. Moscow, Publishing House LKI, 2011. 280 p.

16. TharahovskyY.S., Kim Yu.A., Abdrasilov B.S., Muzafarov E.N. Flavonoids: Biochemistry, Biophysicist, Medicine. Synchrobook, Puschino, 2013.308 p.

17. TharahovskyY.S., Kuznetsov S.M., Vasilyev N.A., Egorochkin M.A., Kim Yu.A. Taxifolin Interaction With Multilamellar Liposomes From Dimitristoylphosphatidylcholine. Biophysicist, 2008, vol. 53, no. 1, pp. 78-84.

\title{
ВЛИЯНИЕ МЕЛАФЕНА НА СТРУКТУРНЫЕ СВОЙСТВА ФОСФОЛИПИДНЫХ МЕМБРАН
}

\author{
Алексеева Ольга Михайловна
}

Кандидат биологических наук, старший научный сотрудник, Институт биохимической физики им. Н.М. Эмануэля РАН olgavek@yandex.ru ул. Косыгина, 4, 119334 г. Москва, Российская Федерация 


\section{ТЕХНИКО-ТЕХНОЛОГИЧЕСКИЕ ИННОВАЦИИ}

\section{Кривандин Алексей Владимирович}

Кандидат физико-математических наук, ведущий научный сотрудник, Институт биохимической физики им. Н.М. Эмануэля РАН olgavek@yandex.ru ул. Косыгина, 4, 119334 г. Москва, Российская Федерация

\section{Шаталова Ольга Владимировна}

Научный сотрудник,

Институт биохимической физики им. Н.М. Эмануэля РАН

olgavek@yandex.ru

ул. Косыгина, 4, 119334 г. Москва, Российская Федерация

\section{Кременцова Анна Владимировна}

Кандидат физико-математических наук, ведущий научный сотрудник, Институт биохимической физики им. Н.М. Эмануэля РАН olgavek@yandex.ru ул. Косыгина, 4, 119334 г. Москва, Российская Федерация

\section{Ким Юрий Александрович}

Доктор физико-математических наук, ведущий научный сотрудник, Институт биологического приборостроения с опытным производством РАН ibp@ibp-ran.ru ул. Институтская, 7, 142290 г. Пущино, Российская Федерация

Аннотация. В работе было исследовано действие водных растворов меламиновой соли фосфоновой кислоты (мелафен), которая используется для растениеводства, на структурные и термодинамические свойства фосфолипидных мембран. Было показано, что строение мембраны, состоящей из отдельных нейтральных фосфолипидов, изменяется в водных растворах мелафена в широком диапазоне концентраций мелафена. В то же время мелафен не влияет на общую структуру липидных мембран, состоящих из природных фосфолипидов смеси.

Ключевые слова: мелафен, липосомы, дифференциальная микрокалориметрия, малоугловое рентгеновского рассеяния. 